\title{
Assessment of the Current and Projected Conditions of Water Availability in the Sevastopol Region for Grape Growing
}

\author{
Elena Vyshkvarkova ${ }^{1, * \mathbb{C}}$, Evgeniy Rybalko ${ }^{2}$, Olesia Marchukova ${ }^{1}$ and Natalia Baranova ${ }^{2}$ \\ 1 Institute of Natural and Technical Systems, 299011 Sevastopol, Russia; olesjath@mail.ru \\ 2 All-Russian National Research Institute of Viticulture and Winemaking 'Magarach' RAS, 298600 Yalta, Russia; \\ rybalko_ye_a@mail.ru (E.R.); natali.v.0468@mail.ru (N.B.) \\ * Correspondence: aveiro_7@mail.ru
}

Citation: Vyshkvarkova, E.; Rybalko, E.; Marchukova, O.; Baranova, N Assessment of the Current and Projected Conditions of Water Availability in the Sevastopol Region for Grape Growing. Agronomy 2021, 11, 1665. https://doi.org/10.3390/ agronomy11081665

Received: 27 July 2021

Accepted: 19 August 2021

Published: 21 August 2021

Publisher's Note: MDPI stays neutral with regard to jurisdictional claims in published maps and institutional affiliations.

Copyright: (c) 2021 by the authors. Licensee MDPI, Basel, Switzerland. This article is an open access article distributed under the terms and conditions of the Creative Commons Attribution (CC BY) license (https:// creativecommons.org/licenses/by/ $4.0 /)$.

\begin{abstract}
Viticulture is a sector very sensitive to climate change. Observed and expected changes in temperature and precipitation can change the conditions necessary for viticulture in a particular area or make these conditions totally unsuitable for viticulture. Precipitation (water availability) and air temperature are the key meteorological parameters regulating the quality of grapes and wine. We used an ensemble of model data from the CMIP6 project to evaluate all possible changes in water availability in the area around Sevastopol by the middle and the end of the 21st century for two Shared Socioeconomic Pathway scenarios (SSP2-4.5 and SSP5-8.5). The hydrothermal coefficient and dryness index have been used to evaluate the water availability. The results have shown that, based on the indices values, viticulture in the study region will be possible without irrigation, but, at the same time, the vines may experience a certain level of dryness.
\end{abstract}

Keywords: viticulture; precipitation; water availability; Sevastopol region; climate change; projections

\section{Introduction}

Air temperature and precipitation are the key meteorological parameters impacting on the growth of grapes (Vitis Vinifera L.). There have been multiple studies conducted in various wine-producing regions on the effect of thermal conditions on vine development, grape ripening, and, as a consequence, the quality of wine (for instance, [1-7]). However, there are a smaller number of studies dedicated to the effect of precipitation on viticulture and an even smaller number of studies evaluating parameters of precipitation (i.e., frequency, duration) on grape phenology [8,9]. The necessity in precipitation and its amount is different based on the season and the stage of development of a grapevine. Precipitation greatly impacts the soil water balance, regulating the availability of water for plants [10]. Seguin first showed the effect of water availability on vine development and wine quality in the 1960s [11,12]. Precipitation is needed during the winter and spring for the soil to accumulate water [13] and at the beginning of vegetation so that the flowers can develop [14]. On the contrary, dry atmospheric conditions are needed during the bloom and ripening of grape berries [15]. High water availability may increase the yield but decrease the sugar content in grape berries [16]. Excessive raining may cause fungal infections and halt pollination [17], as well as delay harvesting [18]. Carlo et al. [8], using the example of one grape variety (raw material for premium wines) from vineyards in central Italy, showed a positive correlation between an earlier harvest time and intense rainfall. At the same time, a severe water deficit may disrupt the ripening process, thereby decreasing the quality of wine $[14,19,20]$. Drought and thermal stress heavily influence the physiological and biochemical features (leaf stomatal conductance and photosynthetic rates) of some varieties of grapes [21]. However, moderate water stress is advantageous in the production of red wine: reduces shoot growth, reduces grape size, and as a consequence the amount of phenol compounds in grape skin increases [22-25]; as for white wines, this can negatively affect not only yields, but also quality [23]. An experiment on the influence of a water 
deficit on the Cabernet Sauvignon variety showed a decrease in the number of bunches on the vine in the period from budding to ripening, and in the period between ripening and harvesting, it increased the acidity of the wine [26]. Research in the Bordeaux area and later in southern Côtes du Rhône (France) has shown that the potential for high quality red grapes is associated with environmental stress, such as limited water availability or moderate nitrogen deficiency $[27,28]$.

Global warming has led to the shift of climate zones, the extension of areas with a dry climate [29] and an increase in extreme weather events related to precipitation [30]. Global models demonstrate that this increase will continue in the future [30]. During summer months, there is a decline in precipitation in European Russia (except the northern regions) and a substantial decline in southern regions [31]. According to the IPCC, the change in precipitation-in case warming persists-will not be homogeneous [30]. According to the RCP8.5 scenario, mean precipitation is likely to decrease in many midlatitude arid regions and in the subtropics, while in many humid midlatitude regions it is likely to increase by the end of this century. Still, the amount of precipitation in Russia will be increasing throughout the 21st century, especially in winter. By the middle of the 21st century, the smallest (on average for the ensemble of models) changes in the amount of summer precipitation are observed in the south of European Russia where there is even a tendency towards their decrease [31].

Precipitation trends in Europe are different. In wine-growing regions of central Italy, an increase in total precipitation and the number of rainy days was observed between 1995 and 2015 [32,33]. A decrease in precipitation between 1998 and 2018 was observed in the south of Romania [34]. According to the results of projections by regional climate models within the framework of the EURO-CORDEX project, the RCP8.5 scenario projected a decrease in annual precipitation in the Mediterranean and southern Europe by the middle of the 21st century. The biggest decrease is observed in the south of Italy, in the Balkans, and in central and southern Spain. In the meantime, central and northern Europe will suffer from increased precipitation [35]. The tendency towards more arid summers is observed in the wine-growing regions of southern Europe, Australia, and South Africa. Precipitation decrease leads to a decrease in grape production in the main European wineproducing countries such as France, Spain, Italy, Germany and Portugal. An average of a $1 \%$ decrease in precipitation leads to a decrease of $0.019 \%$ in output [36]. More humid summers are projected for regions located in higher latitudes such as New Zealand and northern Oregon [37].

Viticulture in Russia is concentrated in small areas in the south of the country, including the Crimean Peninsula. These territories are characterized by heterogeneous climatic conditions, high temperatures and a lack of precipitation during the growing season. According to the meteorological data, the Sevastopol region has sufficient thermal conditions to grow grapes of all maturation terms [38]. Prognostic evaluations obtained from the models in the CORDEX project show that, by the middle and the end of the 21st century, the region will still be suitable for growing high-quality grapes [39]. The results obtained earlier indicate the absence of statistically significant changes in precipitation and their extreme values in the Crimean Peninsula, particularly in the Sevastopol region [40]. This article is a continuation of the cycle of works $[31,32]$ on the analysis of agroclimatic conditions of the Sevastopol region. So, the objective of this study is to examine the current water availability in the Sevastopol region and to evaluate possible future changes in precipitation-based agroclimatic indices by the middle and the end of the 21st century.

\section{Materials and Methods}

\subsection{Study Area}

Wine grapes are traditionally cultivated in the Sevastopol region. At the end of 2020, the total area of grape plantations in the region amounted to 5.9 thousand hectares and 4.7 thousand hectares are fruit-bearing [41]. In 2020, at least 500 hectares of new vines were established. These are largely seedlings of wine grapes such as Pinot Noir, 
Syrah, Riesling, Sauvignon Blanc, Chardonnay, and Merlot. Viticulture in the Crimea and around Sevastopol has existed for more than two thousand years. It started when there were settlements of ancient Greeks in the Crimea. The Greeks built one of the oldest distilleries in the ancient Chersonesus. The priority project "Terroir Sevastopol" is currently being implemented in the region, and it is expected that the development of winemaking infrastructure and the area of vineyards will increase to 10 thousand hectares by 2030 [41]. The regional viticulture is nonirrigated. The region under consideration is located in the southwest of the Crimean Peninsula $\left(33^{\circ} 22^{\prime}-33^{\circ} 54^{\prime} \mathrm{E}, 44^{\circ} 22^{\prime}-44^{\circ} 54^{\prime} \mathrm{N}\right)$. More than half of the territory is in the range of altitudes from 0 to $200 \mathrm{~m}$ above sea level (Figure 1). The Sevastopol region is one of 13 viticulture and winemaking regions of Crimea. The region is located to the west of the main ridge of the Crimean Mountains, and two climatic subzones can be distinguished there. These are the foothill areas with a temperate marine climate and the southeast coast with a subtropical Mediterranean type of climate [38].

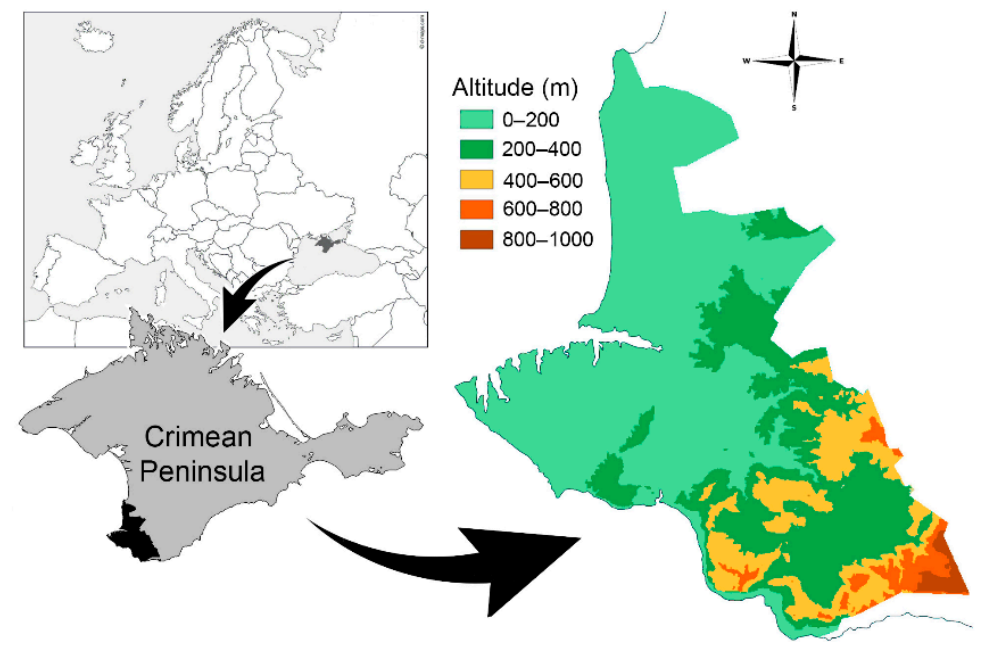

Figure 1. Geographical location and altitude distribution in the Sevastopol region.

\subsection{Data and Methods}

We used daily data on precipitation and average air temperature from the Sevastopol meteorological station for the period between 1991 and $2020\left(44.62^{\circ} \mathrm{N}, 33.53^{\circ} \mathrm{E}\right)$. To analyze future changes in the water availability of the region, we used the results of global climate models of the CMIP Phase 6 project: mean near-surface temperature (tas) and precipitation (pr) [42]. As part of phase 6 of the CMIP project within the framework of the World Climate Research Programme (WCRP), a new set of scenarios has been developed that reflect various socio-economic changes (SSPs, or Shared Socioeconomic Pathways), as well as various ways of anthropogenic changes in the concentration of greenhouse gases in the atmosphere [43]. We used the calculation data under the SSP2-4.5 and SSP5-8.5 scenarios. SSP2-4.5 is the updated RCP4.5 scenario, a "middle of the road" scenario with medium challenges to mitigation and adaptation, when the past and current global development is extrapolated to the future [44]. In the case of SSP2-4.5, the radiative forcing level is $4.5 \mathrm{~W} / \mathrm{m}^{2}$ by 2100 , and the $\mathrm{CO}_{2}$ concentration is $600 \mathrm{ppm}$ [45]. This scenario presupposes that climate protection measures have already been taken. The SSP5-8.5 is an extreme and an unfavorable scenario. The forcing level by 2100 under this scenario is $8.5 \mathrm{~W} / \mathrm{m}^{2}$, and the greenhouse gas concentration is 1100 ppm [45]. Innovation and technology are growing due to the intensive use of fossil fuels [44].

To obtain estimates of future changes in water availability in the region, we used an ensemble of six models from the CMIP6 project: ACCESS-CM2 (Australia), CMCC-CM2-SR5 (Italy), HadGEM3-GC31-LL (UK), INM-CM4-8 (Russia), KACE-1-0-G (South Korea), and NESM3 (China). The analysis is based on the first ensemble member (member_id = r1i1p1f1) of each model. Using an ensemble of model results can reduce the uncertainty associated 
with any single model [46]. The data transfer from the nodes of the model grid to the Sevastopol region was performed by the method of linear interpolation. MATLAB software was used to analyze the datasets.

The materials were a vector map of the Crimean Peninsula, the SRTM-3 digital terrain model, and the Worldclim 2.0 climate model. The modeling of the spatial distribution of the hydrothermal coefficient was carried out based on separate modeling of the two climatic factors that form this coefficient. These are the sum of active temperatures above $10{ }^{\circ} \mathrm{C}$ (using the Sofroni-Entenzon formula with corrections proposed for the Crimean Peninsula [47]) and the precipitation amount for the growing period based on the Worldclim 2.0 model. The use of the adapted formula for the Crimean Peninsula takes into account the following parameters: absolute altitude above sea level for the weather station, relative altitude, aspect and steepness of the slope, distance to the sea, and geographical latitude [38]. The model calculates the difference between the indicator level estimate and the analyzed location based on their differences in terrain and other specified parameters. Modeling of the spatial variation of the dryness index is also based on the Worldclim 2.0 model. In this case, the initial value of the water balance $\left(\mathrm{W}_{0}\right)$ in the region under consideration was taken as $200 \mathrm{~mm}$, and the potential evapotranspiration was $5 \mathrm{~mm}$ a day. The authors applied ArcGIS to simulate agroclimatic indices and visualize the results.

The period between 1981 and 2014 was taken as a base period. There were two other periods-2021 to 2050 and 2051 to 2080. Intervals of 30 years were chosen because a vine is revitalized every 25 to 30 years.

The work analyzes the following parameters of the region's water availability:

- $\quad$ the annual precipitation (in $\mathrm{mm}$ );

- the average growing season precipitation [48]. It is determined as the sum of precipitation during the growing season (between April and October for the Northern hemisphere). It provides information on the effect of precipitation during this period on the phenology and ripening of grape berries, which affects the quality of grapes and the health of the vine [49];

- Selyaninov hydrothermal coefficient (HTC) which shows the region's water availability [50]. It is used in agronomy for a general assessment of the climate and the distribution of zones with different water availability in order to determine the feasibility of growing certain crops (see Table 1);

- the dryness index, or DI [51]. The DI is a climate index used in viticulture to characterize the water component of a region. It is closely related to the quality of grapes and wine [52]. The index takes into account the climatic requirements of the vineyard, evaporation from open soil, and rainfall without deducting surface runoff or drainage. It indicates the potential availability of water in soil related to the level of aridity in the region (see Table 2).

Table 1. Classes of indices used in the paper.

\begin{tabular}{cccc}
\hline Index & Intervals & Definition & Source \\
\hline & $<0.6$ & & \\
Seljaninov's & $0.6-0.7$ & & \\
hydrothermal coefficient & $0.7-0.8$ & insufficient moisture & Seljaninov, G.T., 1966 [50] \\
(HTC) & $0.8-0.9$ & & \\
& $0.9-1.0$ & sufficient hydration & Tonietto J. and \\
& $>1.0$ & DI+2 very dry & Carbonneau A., 2004 [51] \\
\hline
\end{tabular}


Table 2. Distribution of the area (in \%) occupied by the different HTC intervals.

\begin{tabular}{cccccc}
\hline \multirow{2}{*}{ HTC Classes } & \multirow{2}{*}{ Base Period } & \multicolumn{2}{c}{ Period 2021-2050 } & \multicolumn{2}{c}{ Period 2051-2080 } \\
\cline { 3 - 6 } & & SSP2-4.5 & SSP5-8.5 & SSP2-4.5 & SSP5-8.5 \\
\hline$<0.6$ & 16.7 & 31.8 & 45.5 & 64.4 & 76.3 \\
$0.6-0.7$ & 41.6 & 32.6 & 26.4 & 18.0 & 10.6 \\
$0.7-0.8$ & 20.9 & 18.0 & 13.2 & 8.2 & 6.5 \\
$0.8-0.9$ & 9.2 & 8.2 & 7.2 & 4.8 & 3.3 \\
$0.9-1.0$ & 5.9 & 4.8 & 3.9 & 2.2 & 1.5 \\
$>1.0$ & 5.7 & 4.6 & 3.8 & 2.4 & 1.8 \\
\hline
\end{tabular}

Formulas to calculate the indices:

$$
\begin{gathered}
H T C=\frac{P \cdot 10}{\sum t} \\
D I=W_{0}+\sum_{1 A p r}^{31 \text { Oct }}\left[P-\left(E_{t}+E_{s}\right)\right]
\end{gathered}
$$

where $P$-precipitation, $\mathrm{mm} ; \mathrm{W}_{0}$-initial soil moisture, $\mathrm{mm} ; \sum t$ - the sum of active temperatures above $10^{\circ} \mathrm{C}$; Et-the loss of water through transpiration, Es - the amount of water that evaporates from the bare ground.

\section{Results}

\subsection{Current Water Availability of the Sevastopol Region}

The average annual precipitation for the period 1991-2020 was $418 \mathrm{~mm}$ (see Figure 2a). The highest value was $677 \mathrm{~mm}$ (recorded in 1997), and the lowest value was $259 \mathrm{~mm}$ in 1994. The average annual precipitation is characterized by a negative trend of $-15 \mathrm{~mm}$ for 10 years, which is statistically insignificant. The precipitation is distributed uniformly throughout the year. There are two precipitation maxima in the annual precipitation distribution: the summer and the winter maxima (see Figure $2 b$ ). The average precipitation for the seasons is as follows: winter-112 $\mathrm{mm}$, spring $-89 \mathrm{~mm}$, summer $-92 \mathrm{~mm}$, autumn$127 \mathrm{~mm}$. The winter season is characterized by a positive trend, while the other seasons are characterized by a negative trend. All trends are statistically insignificant.

(a)

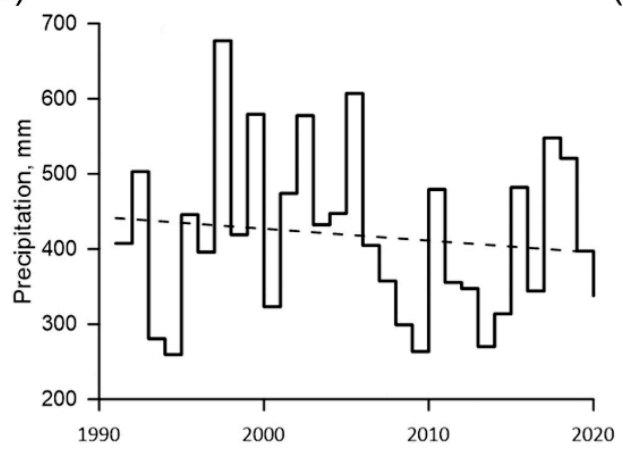

(b)

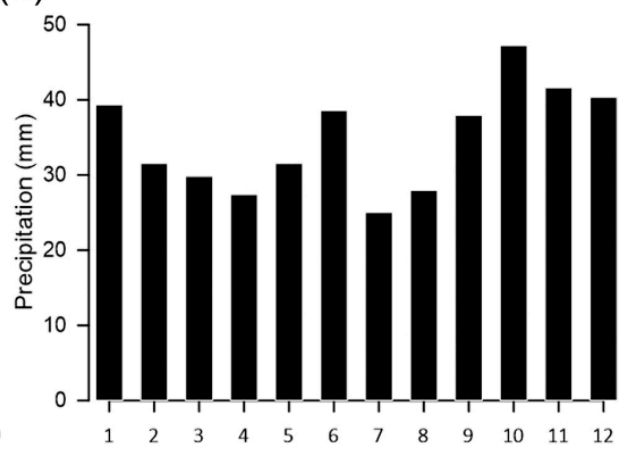

Figure 2. Long-term variation of annual precipitation. The dashed line represents a linear trend (a). Intra-annual distribution of precipitation (b) in Sevastopol between 1991 and 2020.

The average growing season precipitation (between April and October) was $235 \mathrm{~mm}$ for the study period. Both the amount of annual and seasonal precipitation over the growing season tends to decrease. The average growing season precipitation is an important factor in assessing the suitability and economic viability of a given region for grape growing and wine production [53]. However, this parameter must be assessed using adequate indices with predefined threshold values, since there are no precise limits on rainfall for 
determining grape distribution areas [53]. Figure 3 shows the spatial distribution of the hydrothermal coefficient (HTC) and the dryness index (DI). Insufficient moisture is characteristic of $95 \%$ of the region's territory (the HTC is less than one): $27 \%$ of the area has HTC values of less than $0.6 ; 35 \%$-from 0.6 to $0.7 ; 19 \%$-from 0.7 to $0.8 ; 8.5 \%$ of the area-from 0.8 to 0.9 , and $5 \%$ of the area has HTC values from 0.9 to 1.0 . The water availability increases in the southeast direction where the Crimean Mountains are located (see Figure 3a). As for the dryness index, the entire Sevastopol region is located in the "moderately dry" class (DI+1) with values between -20 to $-100 \mathrm{~mm}$ (see Figure $3 \mathrm{~b}$ ). The prevailing range of DI values is from -60 to $-80 \mathrm{~mm}(56.5 \%)$. Thirty-five percent of the region's area (the northern and western parts) has a DI between -80 and $-100 \mathrm{~mm}$.



Figure 3. Spatial distribution of (a) HTC and (b) DI in the Sevastopol region between 1991 and 2020.

\subsection{Prognostic Evaluations}

\subsubsection{Comparing the Observational and Model Data}

A comparison of the observational data and the ensemble of climatic models for air temperature showed a high correlation (the correlation coefficient is 0.88 ). The values of precipitation in the model and the observational data have a low degree of correlation. This is expected because daily precipitation is distributed unevenly throughout the region. The linear trends of the precipitation observations and model data were compared. It showed a coincidence of the trends for the historical period. These tests make it possible to use the ensemble of model data for further calculations of the region's water availability.

For the base period between 1981 and 2014, the average growing season precipitation was $224 \mathrm{~mm}$. Under SSP2-4.5 and between 2021 and 2050, there is a decrease in the amount of precipitation to $198 \mathrm{~mm}$. Within the next period (2051 to 2080), there is a slight increase to $204 \mathrm{~mm}$. Under the SSP5-8.5 scenario, the amount of precipitation is expected to first increase to $227 \mathrm{~mm}$ in the 2021-2050 period (higher than in the base period of 1981 to 2014), and then decrease to $195 \mathrm{~mm}$. In general, there is a trend in the Sevastopol region towards a decrease in the average growing season precipitation by the middle and end of the 21st century.

\subsubsection{Selyaninov‘s Hydrothermal Coefficient (HTC)}

The change of the hydrothermal coefficient over the territory of the Sevastopol region for the two future periods under different scenarios is presented in Table 2 and in Figures 4 and 5. 




Figure 4. Change in areas (in \%) of the Sevastopol region with different HTC values for two future periods under different SSPs relative to the base period (1981-2014).

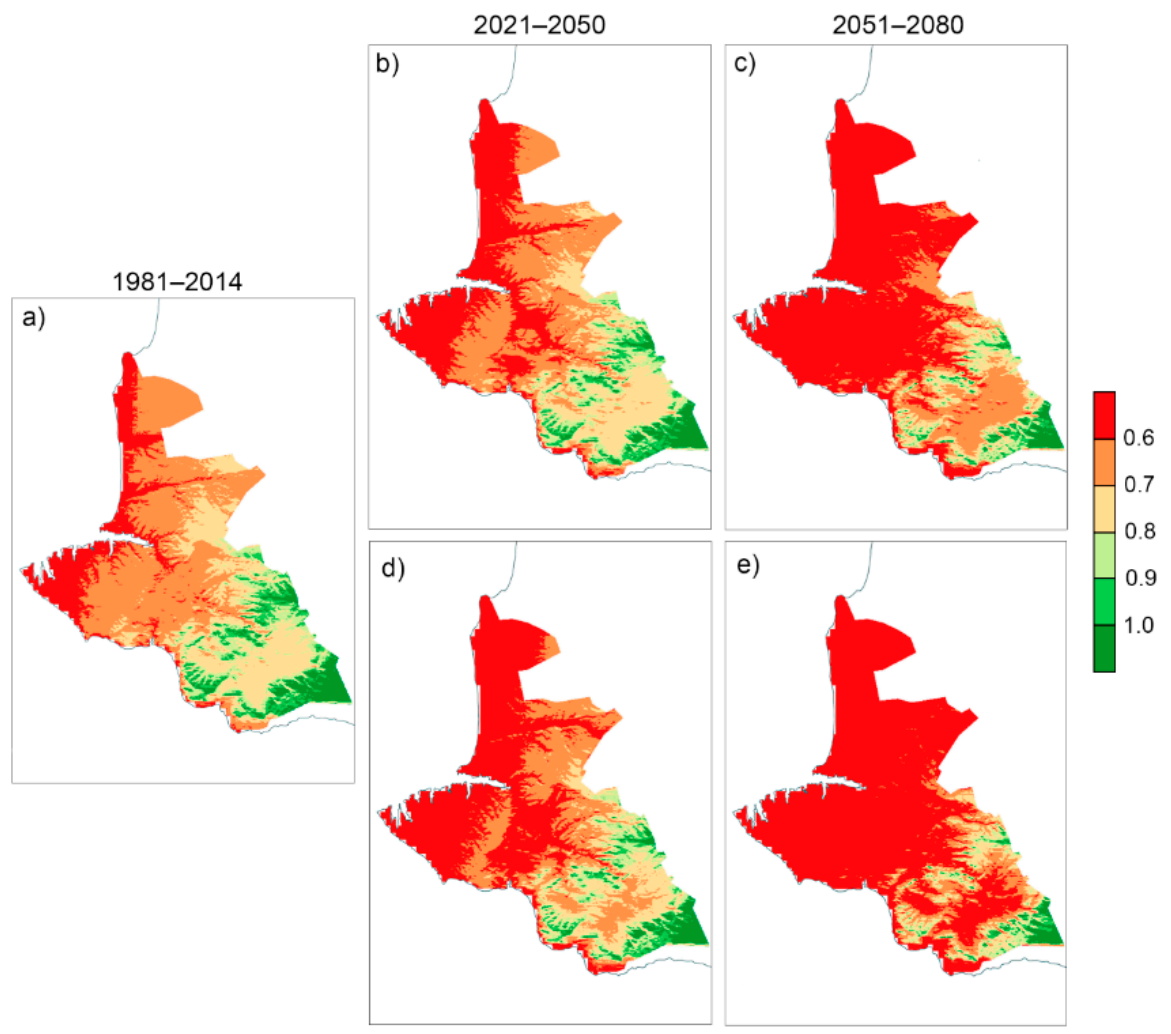

Figure 5. Spatial distribution of HTC over the territory of the Sevastopol region for the base period (a), and the expected changes under SSP2-4.5 (b,c) and SSP5-8.5 (d,e) for future periods.

Figure 4 shows the change in areas with different HTC values by the middle and end of the century relative to the base period (1981-2014). As can be seen, under both SSPs, an increase in the area of the region with HTC values of less than 0.6 is observed due to a decrease in areas with other coefficient intervals. Under the pessimistic SSP5-8.5 scenario in the second future period (2051 to 2080), the region's area with sufficient water availability is reduced to $2 \%$. The spatial distribution of the predicted changes of HTC values in the future periods is shown in Figure 5. 


\subsubsection{Dryness Index (DI)}

According to the values of the dryness index, the entire Sevastopol region in both future periods will be located in the DI +1 , or "moderately dry" class of viticultural climate where the vine can potentially face a certain level of dryness. This is a class with a big degree of value variability between 50 to $-100 \mathrm{~mm}$ [51]. We have divided this class into smaller $20 \mathrm{~mm}$ intervals to see the dynamics of the index under different SSP scenarios by the middle and the end of the century. As can be seen from Table 3, when the SSP scenario changes to a more pessimistic one, the percentage of area with prevailing dryness index values between -80 and -100 increases. These regions can be classified as a Mediterranean type climate with water scarcity in the summer [51]. Thus, by the end of the second future period, the territory of the Sevastopol region is on the verge of transition to the DI+2 class (see Figure 6).

Table 3. Distribution of areas (in \%) with various DI intervals.

\begin{tabular}{cccccc}
\hline \multirow{2}{*}{ DI Intervals } & \multirow{2}{*}{ Base Period } & \multicolumn{2}{c}{ Period 2021-2050 } & \multicolumn{2}{c}{ Period 2051-2080 } \\
\cline { 3 - 6 } & & SSP2-4.5 & SSP5-8.5 & SSP2-4.5 & SSP5-8.5 \\
\hline$-100 \ldots-80$ & 23.7 & 34.5 & 47.2 & 64.7 & 79.6 \\
$-80 \ldots-60$ & 63.8 & 56.8 & 46.1 & 32.5 & 18.7 \\
$-60 \ldots-40$ & 11.5 & 8.0 & 6.2 & 2.8 & 1.7 \\
$-40 \ldots-20$ & 1.0 & 0.7 & 0.5 & 0.0 & 0.0 \\
\hline
\end{tabular}

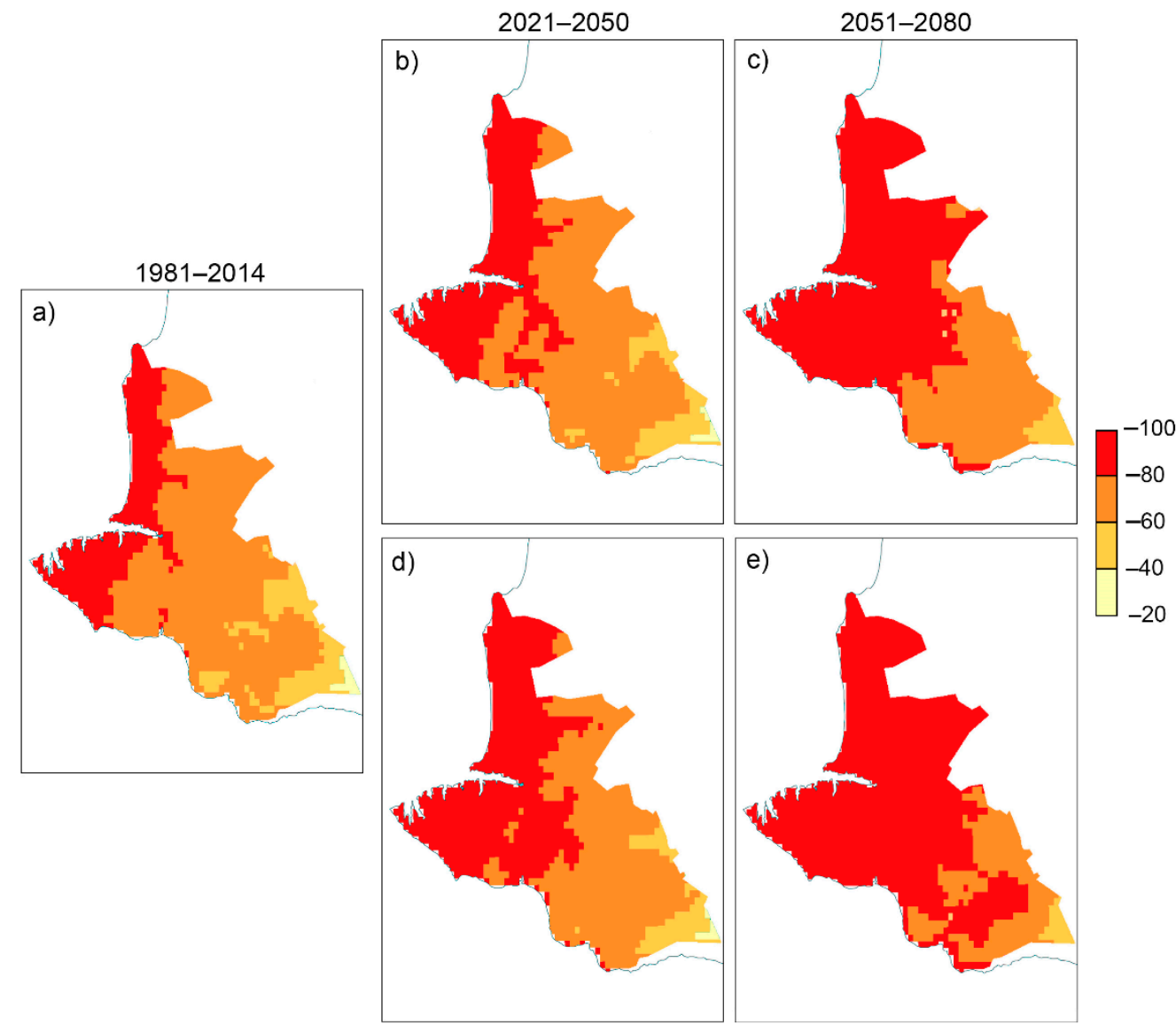

Figure 6. Spatial distribution of the dryness index $(\mathrm{mm})$ in the Sevastopol region for the base period (a) and the expected changes at SSP2-4.5 (b,c) and SSP5-8.5 (d,e) for future periods. 


\section{Discussion and Conclusions}

The analysis of the water availability of the region for the cultivation of grapes and the production of high-quality wine in the future was carried out using various agroecological indices. Based on the ensemble results of the models from the CMIP Phase 6 project, we have estimated possible changes in water availability of the Sevastopol region by the middle and the end of the 21st century. Two precipitation-based indices have been used-the hydrothermal coefficient, or HTC, and the dryness index (DI). The hydrothermal coefficient proposed by Selyaninov [50] describes most fully the conditional balance of moisture and heat. The results showed an increase in the area with HTC values of less than 0.6, which demonstrates the increased aridity of the region. In the nonirrigated zone, the HTC of 0.5 for the growing season is a borderline value when grapes can be cultivated without irrigation $[54,55]$. The HTC values in the current period and future periods indicate that the Sevastopol region remains in the area where the cultivation of grapes is possible without artificial irrigation. Trends towards a decrease in HTC values are typical for the countries of the Black Sea basin [56-59]. The average HTC values of 0.8 for the period 1989-2020 in the region are typical for the Romanian wine region, and in the last year of 2019-2020 it dropped to 0.4 , which led to a low grape harvest [56]. However, not all grape varieties showed a decrease in yield; the Mamaia cultivar, on the contrary, showed a higher yield with high air temperatures and a lack of precipitation, which confirms the need for careful selection of varieties in a changing climate. In 2015, a dry year in Europe, Moldova recorded a decrease in the level of HTC to 0.5, which led to an earlier harvest [57]. According to our results, in the future, the values of HTC will decrease to such values, which may lead to an earlier harvest. A decrease in the level of water availability during the growing and ripening period of grapes was found in the agroecological regions of industrial viticulture of the Krasnodar Territory and the Rostov Region (Russia) [58]. A decreasing trend of HTC values was also observed in Montenegro from 1950 to 2005, however, with higher values due to the more humid Mediterranean climate [59].

According to our estimates by the DI values, the Sevastopol region in the future periods will be in the "moderately dry" class under both scenarios. Our results are consistent with those previously obtained. For instance, Malheiro et al. [60] found that, for the period between 2071 and 2100, the territory of the Crimean Peninsula will be in this DI class. In general, European wine-growing regions are characterized by an increase in aridity in the future, which will be especially prominent in the south, or in the Mediterranean. For the territory of Portugal one report found an increased the dryness index and decreased summer and spring precipitation by the 2070s [61]. According to the EBU-POM regional climate model [62], Bosnia and Herzegovina is expected to shift towards the drier DI class between 2071 and 2100. The increase in aridity for the territory of Hungary by the middle and end of the 21st century was obtained using the Pálfai's drought index [63].

Decreases in precipitation, higher air and soil temperatures, and more frequent and prolonged extreme climatic events (e.g., heatwaves or extreme drought) [30] are predicted to negatively affect some of the viticulture areas in Mediterranean-like climate regions of southern Europe [64,65]. Climatic changes will lead to increased heat stress and water scarcity $[13,66]$, which will require changes in the tillage system [67], the selection of more drought-tolerant rootstocks $[68,69]$, an increase in the water demand of plants and the need for irrigation [68,70,71], as well as the use of different species of wine grapes [9,72], leaf removal and cluster thinning [73-75]. The results obtained are important for selecting adaptation measures to the current and future climate changes in the study region. For instance, the selection of drought-resistant varieties including rootstocks, irrigation, soil mulching, and the placement of vineyards; on the northern, north-eastern and northwestern slopes (with sufficient heat supply to the area), and on the lower part of the slope (in the absence of the threat of frost and with good ventilation conditions). The study needs to be continued due to progressive climate changes. 
Author Contributions: Conceptualization, E.V. and E.R.; methodology, E.R.; software, E.R.; validation, E.R. and O.M.; formal analysis, O.M. and E.R.; investigation, E.V.; data curation, E.R., O.M. and N.B.; writing—original draft preparation, E.V. and O.M.; writing—review and editing, E.V. and E.R.; visualization, E.R., N.B. and E.V.; supervision, E.V.; project administration, E.V.; funding acquisition, E.V. All authors have read and agreed to the published version of the manuscript.

Funding: The reported study was funded by RFBR and Sevastopol, project number 20-45-920008.

Data Availability Statement: The initial time series of daily data of the average air temperature and precipitation are on the website WCRP Coupled Model Intercomparison Project (Phase 6) https: / / esgf-index1.ceda.ac.uk/search/cmip6-ceda/ (accessed on 10 May 2021).

Conflicts of Interest: The authors declare no conflict of interest.

\section{References}

1. Venios, X.; Korkas, E.; Nisiotou, A.; Banilas, G. Grapevine Responses to Heat Stress and Global Warming. Plants 2020, 9, 1754. [CrossRef]

2. Fraga, H.; Pinto, J.G.; Santos, J.A. Climate change projections for chilling and heat forcing conditions in European vineyards and olive orchards: A multi-model assessment. Clim. Chang. 2019, 152, 179-193. [CrossRef]

3. Gutiérrez-Gamboa, G.; Zheng, W.; de Toda, F.M. Current viticultural techniques to mitigate the effects of global warming on grape and wine quality: A comprehensive review. Food Res. Int. 2020, 139, 109946. [CrossRef] [PubMed]

4. Bois, B.; Joly, D.; Quénol, H.; Pieri, P.; Gaudillère, J.-P.; Guyon, D.; Saur, E.; Van Leeuwen, C. Temperature-based zoning of the Bordeaux wine region. OENO One 2018, 52, 291-306. [CrossRef]

5. Jones, G.V.; White, M.; Cooper, O.R.; Storchmann, K. Climate Change and Global Wine Quality. Clim. Chang. 2005, 73, 319-343. [CrossRef]

6. Neethling, E.; Barbeau, G.; Coulon-Leroy, C.; Quénol, H. Spatial complexity and temporal dynamics in viticulture: A review of climate-driven scales. Agric. For. Meteorol. 2019, 276-277, 107618. [CrossRef]

7. Bernáth, S.; Paulen, O.; Šiška, B.; Kusá, Z.; Tóth, F. Influence of Climate Warming on Grapevine (Vitis vinifera L.) Phenology in Conditions of Central Europe (Slovakia). Plants 2021, 10, 1020. [CrossRef]

8. Di Carlo, P.; Aruffo, E.; Brune, W.H. Precipitation intensity under a warming climate is threatening some Italian premium wines. Sci. Total. Environ. 2019, 685, 508-513. [CrossRef]

9. Wolkovich, E.M.; De Cortázar-Atauri, I.G.; Morales-Castilla, I.; Nicholas, K.A.; Lacombe, T. From Pinot to Xinomavro in the world's future wine-growing regions. Nat. Clim. Chang. 2018, 8, 29-37. [CrossRef]

10. Santos, J.A.; Fraga, H.; Malheiro, A.C.; Moutinho-Pereira, J.; Dinis, L.-T.; Correia, C.; Moriondo, M.; Leolini, L.; DiBari, C.; Costafreda-Aumedes, S.; et al. A Review of the Potential Climate Change Impacts and Adaptation Options for European Viticulture. Appl. Sci. 2020, 10, 3092. [CrossRef]

11. Seguin, G. L'alimentation en eau de la vigne dans des sols du Haut-Médoc. OENO One 1969, 3, 93-141. [CrossRef]

12. van Leeuwen, C. Terroir: The effect of the physical environment on vine growth, grape ripening and wine sensory attributes. In Managing Wine Quality. Viticulture and Wine Quality; Woodhead Publishing Series in Food Science; Technology and Nutri-tion; Elsevier: Amsterdam, The Netherlands, 2010; pp. 273-315. [CrossRef]

13. Gladstones, J. Wine, Terroir and Climate Change; Wakefield Press: Kent Town, Australia, 2011; 280p.

14. Novikova, L.Y.; Naumova, L.G. Dependence of Fresh Grapes and Wine Taste Scores on the Origin of Varieties and Weather Conditions of the Harvest Year in the Northern Zone of Industrial Viticulture in Russia. Agronomy 2020, 10, 1613. [CrossRef]

15. Jones, G.V.; Davis, R.E. Climate Influences on grapevine phenology, grape composition, and wine production and quality for Bordeaux, France. Am. J. Enol. Vitic. 2000, 51, 249-261.

16. Lorenzo, M.N.; Taboada, J.; Lorenzo, J.F.; Ramos, A. Influence of climate on grape production and wine quality in the Rías Baixas, north-western Spain. Reg. Environ. Chang. 2013, 13, 887-896. [CrossRef]

17. Shaw, T.B. Climate change and the evolution of the Ontario cool climate wine regions in Canada. J. Wine Res. 2016, 28, 13-45. [CrossRef]

18. Cook, B.I.; Wolkovich, E.M. Climate change decouples drought from early wine grape harvests in France. Nat. Clim. Chang. 2016, 6, 715-719. [CrossRef]

19. De Orduña, R.M. Climate change associated effects on grape and wine quality and production. Food Res. Int. 2010, 43, 1844-1855. [CrossRef]

20. Wheeler, S.J.; Pickering, G.J. The effects of soil management techniques on grape and wine quality. In Fruits: Growth, Nutrition and Quality; Dris, R., Ed.; Meri-Rastilan tie 3 C; WFL Publisher: Helsinki, Finland, 2006; pp. 195-208. ISBN 978-952-99555-0-3.

21. Tzortzakis, N.; Chrysargyris, A.; Aziz, A. Adaptive Response of a Native Mediterranean Grapevine Cultivar Upon Short-Term Exposure to Drought and Heat Stress in the Context of Climate Change. Agronomy 2020, 10, 249. [CrossRef]

22. Ojeda, H.; Andary, C.; Kraeva, E.; Carbonneau, A.; Deloire, A. Influence of pre- and postveraison water deficit on synthesis and concentration of skin phenolic compounds during berry growth of Vitis vinifera cv. Syrah. Am. J. Enol. Vitic. 2002, 53, $261-267$. 
23. Van Leeuwen, C.; Destrac-Irvine, A.; Dubernet, M.; Duchêne, E.; Gowdy, M.; Marguerit, E.; Pieri, P.; Parker, A.; De Rességuier, L.; Ollat, N. An Update on the Impact of Climate Change in Viticulture and Potential Adaptations. Agronomy 2019, 9, 514. [CrossRef]

24. Casassa, L.F.; Keller, M.; Harbertson, J.F. Regulated deficit irrigation alters anthocyanins, tannins and sensory proper-ties of Cabernet sauvignon grapes and wines. Molecules 2015, 20, 7820-7844. [CrossRef]

25. Van Leeuwen, C.; Trégoat, O.; Choné, X.; Bois, B.; Pernet, D.; Gaudillère, J.-P. Vine water status is a key factor in grape ripening and vintage quality for red Bordeaux wine. How can it be assessed for vineyard management purposes? OENO One 2009, 43, 121-134. [CrossRef]

26. Ferreyra, R.; Selles, G.; Peralta, J.; Valenzuela, J. Effect of water stress applied at different development periods of cabernet sauvignon grapevine on production and wine quality. Acta Hortic. 2004, 646, 27-33. [CrossRef]

27. Coipel, J.; Lovelle, B.R.; Sipp, C.; Van Leeuwen, C. "Terroir" effect, as a result of enviromental stess, depends more on soil depth than on soil type (Vitis vinifera L. cv. Grenache Noir, Côtes du Rhône, France, 2000). OENO One 2006, 40, 177-185. [CrossRef]

28. van Leeuwen, C.; Friant, P.; Choné XTregoat, O.; Koundouras, S.; Dubourdieu, D. Influence of Climate, Soil, and Cultivar on Terroir. Am. J. Enol. Vitic. 2004, 55, 207-217.

29. Jia, G.; Shevliakova, E.; Artaxo, P.; Noblet-Ducoudré, D.; Houghton, R.; House, J.; Kitajima, K.; Lennard, C.; Popp, A.; Sirin, A.; et al. Land-climate interactions. In Climate Change and Land: An IPCC Special Report on Climate Change, Desertification, Land Degradation, Sustainable Land Management, Food Security, and Greenhouse Gas Fluxes in Terrestrial Ecosystems; Shukla, P.R., Skea, J., Buendia, E.C., Masson-Delmotte, V., Pörtner, H.-O., Roberts, D.C., Zhai, P., Slade, R., Connors, S., van Diemen, R., et al., Eds.; 2019; in press.

30. Core Writing Team; Pachauri, R.K.; Meyer, L.A. (Eds.) IPCC Climate Change 2014: Synthesis Report; Contribution of Working Groups I, II and III to the Fifth Assessment Report of the Intergovernmental Panel on Climate Change; IPCC: Geneva, Switzerland, 2014; 151p.

31. Second Roshydromet Assessment Report on Climate Change and Its Consequences in Russian Federation; General Summary; Roshydromet: Moscow, Russia, 2014; 56p.

32. Biasi, R.; Brunori, E.; Ferrara, C.; Salvati, L. Assessing Impacts of Climate Change on Phenology and Quality Traits of Vitis vinifera L.: The Contribution of Local Knowledge. Plants 2019, 8, 121. [CrossRef] [PubMed]

33. Ramos, M.C.; Jones, G.V.; Martinez-Casasnovas, J.A. Structure and trends I climate parameters affecting winegrape produc-tion in northeast Spain. Clim Res. 2008, 38, 1-15. [CrossRef]

34. Bucur, G.; Cojocaru, G.; Antoce, A. The climate change influences and trends on the grapevine growing in Southern Romania: A long-term study. BIO Web Conf. 2019, 15, 01008. [CrossRef]

35. Cardell, M.F.; Amengual, A.; Romero, R. Future effects of climate change on the suitability of wine grape production across Europe. Reg. Environ. Chang. 2019, 19, 2299-2310. [CrossRef]

36. Bardaji, I.; Iraizoz, B. Uneven responses to climate and market influencing the geography of high-quality wine production in Europe. Reg. Environ. Chang. 2014, 15, 79-92. [CrossRef]

37. Webb, L.; Watterson, I.; Bhend, J.; Whetton, P.; Barlow, E. Global climate analogues for winegrowing regions in future periods: Projections of temperature and precipitation. Aust. J. Grape Wine Res. 2013, 19, 331-341. [CrossRef]

38. Vyshkvarkova, E.V.; Rybalko, E.A.; Baranova, N.V.; Voskresenskaya, E.N. Favorability Level Analysis of the Sevastopol Region's Climate for Viticulture. Agronomy 2020, 10, 1226. [CrossRef]

39. Vyshkvarkova, E.; Rybalko, E. Forecast of Changes in Air Temperatures and Heat Indices in the Sevastopol Region in the 21st Century and Their Impacts on Viticulture. Agronomy 2021, 11, 954. [CrossRef]

40. Vyshkvarkova, E. Changes in extreme precipitation over the North Caucasus and the Crimean Peninsula during 1961-2018. Q. J. Hung. Meteorol. Serv. 2021, 125, 321-336. [CrossRef]

41. Socioeconomic Development Strategy of the City of Sevastopol; Legislative Assembly of the City of Sevastopol: Sevastopol, Russia, 2017; 171p.

42. Eyring, V.; Bony, S.; Meehl, G.A.; Senior, C.A.; Stevens, B.; Stouffer, R.J.; Taylor, K.E. Overview of the Coupled Model Intercomparison Project Phase 6 (CMIP6) experimental design and organization. Geosci. Model Dev. 2016, 9, 1937-1958. [CrossRef]

43. Meinshausen, M.; Nicholls, Z.R.J.; Lewis, J.; Gidden, M.J.; Vogel, E.; Freund, M.; Beyerle, U.; Gessner, C.; Nauels, A.; Bauer, N.; et al. The shared socio-economic pathway (SSP) greenhouse gas concentrations and their extensions to 2500. Geosci. Model Dev. 2020, 13, 3571-3605. [CrossRef]

44. Riahi, K.; van Vuuren, D.P.; Kriegler, E.; Edmonds, J.; O’Neill, B.C.; Fujimori, S.; Bauer, N.; Calvin, K.; Dellink, R.; Fricko, O.; et al. The Shared Socioeconomic Pathways and their energy, land use, and greenhouse gas emissions implications: An overview. Glob. Environ. Chang. 2017, 42, 153-168. [CrossRef]

45. O'Neill, B.C.; Tebaldi, C.; van Vuuren, D.P.; Eyring, V.; Friedlingstein, P.; Hurtt, G.; Knutti, R.; Kriegler, E.; Lamarque, J.-F.; Lowe, J.; et al. The Scenario Model Intercomparison Project (ScenarioMIP) for CMIP6. Geosci. Model Dev. 2016, 9, 3461-3482. [CrossRef]

46. Intergovernmental Panel on Climate Change (IPCC). Good Practice Guidance Paper on Assessing and Combining Multi Model Climate Projections; National Center for Atmospheric Research: Boulder, CO, USA, 2010.

47. Rybalko, E.A. Adaptation of the mathematical model of the spatial distribution of heat supply in the territory in order to efficiently place industrial vineyards on the territory of the Crimean Peninsula. Vinograd. Vinodel. 2014, 2, 10-11.

48. Blanco-Ward, D.; Queijeiro, J.M.G.; Jones, G.V. Spatial climate variability and viticulture in the Mano River valley of Spain. Vitis 2007, 46, 63-70. [CrossRef] 
49. Cabré, F.; Nuñez, M. Impacts of climate change on viticulture in Argentina. Reg. Environ. Chang. 2020, 20, 12. [CrossRef]

50. Seljaninov, G.T. Agroclimatic Map of the World; Gidrometeoizdat: Leningrad, Russia, 1966; 12p.

51. Tonietto, J.; Carbonneau, A. A multicriteria climatic classification system for grape-growing regions worldwide. Agric. For. Meteorol. 2004, 124, 81-97. [CrossRef]

52. Tonietto, J.; Ruiz, V.S.; Gomez-Miguel, V.D. (Eds.) Clima, Zonification y Tipicidad del Vino en Regiones Vitivinicolas Iberoamericanas; CYTED: Madrid, Spain, 2012; 411p.

53. Santos, J.; Malheiro, A.; Pinto, J.G.; Jones, G.; Dos Santos, J.C.A.; Malheiro, A. Macroclimate and viticultural zoning in Europe: Observed trends and atmospheric forcing. Clim. Res. 2012, 51, 89-103. [CrossRef]

54. Smirnov, K.V.; Maltabar, L.M.; Radzhabov, A.K.; Matuzok, N.V.; Troshin, L.P. Vinogradarstvo; FGBNU «Rosinforma-grotekh»: Moscow, Russia, 2017; 500p.

55. Davitaia, F.F. Climatic Zones of Grapes in the USSR; Pishchepromizdat: Moscow, Russia, 1948; 192p.

56. Dina, I.; Ranca, A.; Tănase, A.; Ene, S.-A. Behavior of some grapevine cultivars from murfatlar vineyard in the special climatic conditions of the wine year 2019-2020. Romanian J. Hortic. 2020, 1, 133-140. [CrossRef]

57. Puțuntică, A.; Motruc, A. Meteorological and agrometeorological weather characterization of summer drought of 2015, in the Republic of Moldova. Present. Environ. Sustain. Dev. 2017, 11, 83-89. [CrossRef]

58. Petrov, V.S.; Aleynikova, G.Y.; Novikova, L.Y.; Naumova, L.G.; Lukyanova, A.A. The influence of climate changes the grape phenology. Fruit Grow. Vitic. South Russ. 2019, 57, 29-50. [CrossRef]

59. Savić, S.; Vukotić, M. Viticulture Zoning in Montenegro. Bull. UASVM Hortic. 2018, 75, 73-86. [CrossRef]

60. Malheiro, A.C.; Santos, J.A.; Pinto, J.G.; Jones, G.V. European viticulture geography in a changing climate. Bull. de l'OIV 2012, 85, 15-22.

61. Fraga, H.; Atauri, I.G.D.C.; Malheiro, A.C.; Moutinho-Pereira, J.; Dos Santos, J.C.A. Viticulture in Portugal: A review of recent trends and climate change projections. OENO One 2017, 51, 61-69. [CrossRef]

62. Trbic, G.; Djurdjevic, V.I.; Mandic, M.V.; Ivanisevic, M.; Cupac, R.; Bajic, D.; Zahirovic, E.; Filipovic, D.; Dekic, R.; Popov, T.; et al. The impact of climate change on grapevines in Bosnia and Herzegovina. Euro-Mediterr. J. Environ. Integr. 2020, 6, 4. [CrossRef]

63. Buzási, A. Climate Vulnerability and Adaptation Challenges in Szekszárd Wine Region, Hungary. Climate 2021, 9, 25. [CrossRef]

64. Costa, J.; Vaz, M.; Escalona, J.; Egipto, R.; Lopes, C.; Medrano, H.; Chaves, M. Modern viticulture in southern Europe: Vulnerabilities and strategies for adaptation to water scarcity. Agric. Water Manag. 2015, 164, 5-18. [CrossRef]

65. Droulia, F.; Charalampopoulos, I. Future Climate Change Impacts on European Viticulture: A Review on Recent Scientific Advances. Atmosphere 2021, 12, 495. [CrossRef]

66. Fraga, H.; de Cortazar-Atauri, I.G.; Malheiro, A.C.; Santos, J.A. Modelling climate change impacts on viticultural yield, phenology and stress conditions in Europe. Glob. Chang. Biol. 2016, 22, 3774-3788. [CrossRef] [PubMed]

67. Bahar, E.; Yasasin, A.S. The yield and berry quality under different soil tillage and clusters thinning treatments in grape (Vitis vinifera L.) cv. Cabernet-Sauvignon. Afr. J. Agric. Res. 2010, 5, 2986-2993.

68. Santillán, D.; Garrote, L.; Iglesias, A.; Sotes, V. Climate change risks and adaptation: New indicators for Mediterranean viticulture. Mitig. Adapt. Strat. Glob. Chang. 2019, 25, 881-899. [CrossRef]

69. Keller, M.; Mills, L.J.; Harbertson, J.F. Rootstock Effects on Deficit-Irrigated Winegrapes in a Dry Climate: Vigor, Yield Formation, and Fruit Ripening. Am. J. Enol. Vitic. 2011, 63, 29-39. [CrossRef]

70. Jagosz, B.; Rolbiecki, S.; Stachowski, P.; Ptach, W.; Łangowski, A.; Kasperska-Wołowicz, W.; Sadan, H.; Rolbiecki, R.; Prus, P.; Kazula, M. Assessment of Water Needs of Grapevines in Western Poland from the Perspective of Climate Change. Agriculture 2020, 10, 477. [CrossRef]

71. Jagosz, B.; Rolbiecki, S.; Rolbiecki, R.; Łangowski, A.; Sadan, H.; Ptach, W.; Stachowski, P.; Kasperska-Wołowicz, W.; Pal-Fam, F.; Liberacki, D. The Water Needs of Grapevines in Central Poland. Agronomy 2021, 11, 416. [CrossRef]

72. Maistrenko, A.; Maistrenko, L.; Duran, N.; Matveeva, N. White technical variety of Platovsky grapes for quality ecological winemaking. E3S Web Conf. 2021, 273, 01010. [CrossRef]

73. Keller, M.; Smithyman, R.P.; Mills, L.J. Interactive effects of deficit irrigation and crop load on Cabernet sauvignon in an arid climate. Am. J. Enol.Vitic. 2008, 59, 221-234.

74. Cook, M.G.; Zhang, Y.; Nelson, C.J.; Gambetta, G.; Kennedy, J.A.; Kurtural, S.K. Anthocyanin Composition of Merlot is Ameliorated by Light Microclimate and Irrigation in Central California. Am. J. Enol. Vitic. 2015, 66, 266-278. [CrossRef]

75. Poni, S.; Gatti, M.; Palliotti, A.; Dai, Z.; Duchêne, E.; Truong, T.-T.; Ferrara, G.; Matarrese, A.M.S.; Gallotta, A.; Bellincontro, A.; et al. Grapevine quality: A multiple choice issue. Sci. Hortic. 2018, 234, 445-462. [CrossRef] 